\title{
The Feasibility of Archipelago Children Literature Teaching Materials on Text-Based of Class V SDN 067091 Medan Kota Sub-district, Indonesia
}

\author{
Dahlia $^{1}$, Wisman Hadi ${ }^{2}$, M. Oky Fardian G. ${ }^{2}$ \\ ${ }^{1}$ Ph.D Student in State University of Medan (Unimed), Indonesia \\ ${ }^{2}$ Lecturer in State University of Medan (Unimed), Indonesia \\ dahliazainal123@gmail.com
}

\begin{abstract}
This study aims to know the feasibility of archipelago children literature teaching materials on text-based of class V SDN 067091 Medan Kota sub-district, Indonesia. The type of this study is research and development which is the development of archipelago children literature teaching materials on text-based that deserve to support literature learning in elementary school. The product of archipelago children literature teaching materials is developed to support literary learning in elementary schools have met the requirements and are feasible to use based on the validation of material experts and design. The response to archipelago children literature teaching materials on text-based in literary material is very good and in accordance with the needs of students. It concludes that the use of archipelago children literature teaching materials on text-based is more effective in improving student learning outcomes. This was revealed from the student learning outcomes after being taught with developed teaching materials, namely an increase in learning outcomes from the average 78.98 with a good category to 86.11 with a very good category.
\end{abstract}

Keywords : teaching materials; feasibility; elementary school

\section{Introduction}

The development of teaching materials is the efforts made in improving the quality of learning. The general perception inherent among educators in designing and compiling teaching materials is still said to be difficult and stressful work (Prastowo, 2015: 14). The statement was also relevant when researchers conducted interviews with two teachers in Public Elementary School of 067091, namely, Rodiah S. Pd and Ratna sari lubis S.Pd, that the teaching materials used during the learning process were entirely sourced from publishers. Therefore, ready-to-use teaching materials are still used as the main source by the teacher in the learning process, even though the teaching material is not necessarily in accordance with the needs of students.

The role of the teacher as the person who knows best about their students should be used to develop their creativity in fulfilling basic needs for students, but this is not only in accordance with what happens in the field. This is also revealed from the results of research conducted by Sihotang (2016) and Windyariani (2016) that teaching materials that are conventional in nature without any further development process are still the main choice for educators. The difficulty of developing teaching materials fosters a pragmatic attitude among educators, even though the quality of books circulating in the market has not yet been ascertained by their weight or quality because sometimes they only emphasize mission in the delivery of mere knowledge or facts (Wena, 2014: 229). Therefore, there needs to be an assessment from the parties involved in providing solutions for the education of our children in the future.

The development of teaching materials is very important to support the learning process in classrooms. there are many reasons why teachers need to develop teaching materials, that is because the availability of teaching materials is the demand of the curriculum. The 
development of teaching materials by teachers tends to have a more appropriate level of target characteristics (learners), because generally consider the social, cultural, and geographical environment, student development stages, initial abilities that have been mastered, interests, family background, etc. The development of teaching materials by teachers is expected to be able to answer or solve problems or difficulties in learning, not vice versa. If the learning material to be delivered is abstract, then the teaching material must be able to help students describe something abstract, for example by using images, photos, charts, schemes, etc. Teaching materials differ from textbooks. Good teaching materials are designed according to instructional principles. Teachers can write their own teaching materials that they want to use in teaching and learning activities (KBM). However, teachers can also use textbooks or other materials and information that are already on the market to be repackaged or arranged in such a way that they can be used as teaching materials. Teaching materials are usually equipped with guidelines for students and teachers.

Guidelines are useful for facilitating students and teachers to use teaching materials. Some principles that need to be considered in preparing teaching materials include the principles of relevance, consistency, and sufficiency with the standard competencies and basic competencies targeted. Widdowson (in Martono, 2010: 118) describes the teaching material or literature learning material, namely teaching material must have two principles. First, literary teaching materials must pay attention to the existence of literary theory as a discipline relating to the set of concepts, ways of thinking, and discoveries relating to the existence of literary works.

\section{Review of Literatures}

\subsection{Teaching Materials}

Widodo and Jasmadi in Ika Lestari (2013: 1) state that teaching materials are a set of learning tools or tools that contain learning material, methods, boundaries, and ways of evaluating systematically and interestingly in order to achieve the expected goals, namely achieving competence and sub-competence in all its complexity.

This understanding illustrates that teaching materials should be designed and written in accordance with learning rules that is adjusted learning materials, arranged based on learning needs, there are assessment materials, and teaching materials are interesting to learn by students. Skandarwassid and Dadang Sunendar (2011: 171) revealed that teaching material is a set of information that students must absorb through pleasant learning. This shows that in the preparation of teaching materials it is expected that students really feel the benefits of the teaching material or the material after he learns it.

Yana Wardhana (2010: 29) added that teaching materials are a medium to achieve desires or goals to be achieved by students. Whereas according to Opara and Oguzor (2011: 66) revealed that the instructional materials are the audio visual materials (software / hardware) which can be used as alternative channels of communication in the teaching-learning process. Teaching materials are learning resources in the form of visual and audiovisual which can be used as alternative channels for communication in the learning process.

Based on the study above, the term teaching material used in this study is a systematic material / subject matter that is used by teachers and students in learning Indonesian in elementary school to achieve the expected goals. 
According to the National Center for Competency Based Training (2007), the understanding of teaching materials is all forms of material used to help teachers or instructors in carrying out the learning process. The intended material can be either written or unwritten material. The views of other experts say that teaching materials are a set of materials that are arranged systematically, both written and unwritten, so as to create an environment or atmosphere that allows students to learn.

According to Harvest (2001) revealed that teaching materials are materials or subject matter that are arranged systematically, which are used by teachers and students in learning processes (Andi, 2011: 16).

\subsection{The Nature of Children's Literature.}

Conceptually, children's literature is not much different from adult literacy. Both are in the area of literature which includes life with all feelings, thoughts and insights of life. The difference is only in terms of the focus of giving a meaningful picture of life to the child described in the work. Literature (in children's literature) is an imaginative form of creation with exposure to certain languages that describe the imaginary world, presenting certain understandings and experiences, and containing aesthetic values certain that can be made by adults or children.

Whether children's literature is literature written by adults intended for children or literature written by children for their own circles is not questionable. Huck (1987: 86) suggests that anyone who writes children's literature does not need to be disputed as long as the description is emphasized in the lives of children who have a meaningful value for them. Children's literature is literature that reflects children's feelings and experiences through children's views (Norton, 1993). However, in reality, the value of meaningfulness for children is sometimes seen and measured from an adult's perspective.

Hunt (1995), in Nurgiantoro (2005: 76) defines children's literature by departing from the needs of children. He argues that children's literature can defined as a reading book that is read by children, which is specifically suitable for, and which specifically satisfies a group of members who are now referred to as children. So, children's literature is a reading book that is deliberately written to be consumed for children, books that contain content according to the interests and world of children, according to the level of children's emotional and intellectual development, and books that can therefore satisfy children. The definition of children's literature above certainly explains children's literature extensively. The definition of children referred to in children's literature here is not children under five and not teenagers, but children aged between 6-13 years (Santoso et al: 8.3).

\subsection{The Selection of Folk Stories as Literary Reading Materials in Elementary School}

According to Haryati (2007: 9), teaching materials or learning material outline consists of knowledge, skills, and attitudes that students must learn in order to achieve predetermined competency standards. In detail, the types of learning material consist of knowledge (facts, concepts, principles, procedures) skills, attitudes or values. According to Azis (2010: 88), the problem of teaching materials is important which is often faced by teachers when choosing or determining material because in the curriculum (syllabus) is only written in broad outline in the form of the subject matter. In the 2013 Indonesian Language Curriculum Elementary level learning folklore is included in the competency standards that must be taught by teachers in literary learning material. This shows that folklore stories is material that can support the purpose of learning literature in school. 


\subsection{Definition of Archipelago}

According to the Indonesian Wikipedia, Archipelago is a term used to describe an archipelago that stretches from Sumatra to Papua, which is now largely a territory of the country Indonesia. This word was first recorded in Javanese literature in the middle (12th to 16th century) to describe the concept of state adopted by Majapahit. After being forgotten, at the beginning of the 20th century this term was revived by Ki Hajar Dewantara as one of an alternative name for an independent East Indies progress state that has not yet materialized. When the use of the name "Indonesia" (meaning the Indian Islands) was agreed to be used for this idea, the word Nusantara remained used as a synonym for the Indonesian archipelago. This understanding has until now been used in Indonesia. As a result of subsequent political development, this term was then used to describe the unity of the archipelagic geographies located between the continents of Asia and Australia, including the Malay Peninsula, but usually does not cover the Philippines. In this last sense, the Archipelago was the equivalent of the Malay Archipelago, a term popular in the late 19th century to the beginning of the 20th century, especially in English-language literature.

\subsection{Definition of Text}

"Learning text-based languages" is also called "genre-based language learning". If so, is text the same as genre? On the other hand, if text is equated with discourse, is -text and discourse is the same?

Text is a unit of language that is provided in writing or verbally with certain organizational arrangements to express meaning in certain contexts as well (Compare with Wiratno, 2003: 3-4).

\section{Research Methods}

This research was conducted in class V of 067091 Public Elementary School in Medan City with a total of students is 18 . Then, the implementation of this research was conducted from February to March 2019.

The type of research is Research and Development which is the development of Textbased archipelago Children's Literature teaching materials that deserve to support Literature Learning in elementary schools. According to Sugiyono (2016: 297) research and development methods are research methods used to produce certain products and test the effectiveness of these products. Development research is powerful enough to improve learning practices and products that already exist. This development research refers to the theory of the development of teaching materials proposed by Borg and Gall.

\section{Discussion}

The results of the feasibility of teaching materials are obtained after going through the validation process by material experts and design. The two experts gave an assessment of the teaching materials developed with the aim that the teaching materials were appropriate to be used and applied during the learning process. The data collected through the assessment given by the material experts and the design is then analyzed so that it can be said whether or not a 
product is developed. The following will be presented in the assessment aspects collected from the two experts.

Aspects assessed by material experts on teaching materials developed include content, presentation feasibility, and language feasibility. The assessment of teaching materials developed was carried out by Prof. Amrin Saragih, M.A., Ph.D., and Dr. Shafwan Hadi Umry., Who are lecturers at one of the universities in the city of Medan. The data from the material expert validation on the aspects of content eligibility can be seen in table 1 below.

Table 1. The Assessment of Material Expert on Teaching Materials which Developed on Aspects of Content Feasibility

\begin{tabular}{|c|c|c|c|}
\hline Sub Component & Indicators & $\begin{array}{l}\text { Average } \\
(\%)\end{array}$ & Criteria \\
\hline \multirow[t]{2}{*}{$\begin{array}{l}\text { A. Conformity of materia } \\
\text { with } \mathrm{KI} \text { and } \mathrm{KD}\end{array}$} & $\begin{array}{l}\text { 1. Completeness of children's } \\
\text { literary material (structure, } \\
\text { rules language) }\end{array}$ & $100 \%$ & Very good \\
\hline & $\begin{array}{l}\text { 2. Extent of literary text material } \\
\text { child }\end{array}$ & $88 \%$ & Very good \\
\hline \multirow[t]{5}{*}{ B. Material accuracy } & $\begin{array}{l}\text { 3. Accuracy of concepts and } \\
\text { definition of children's literature }\end{array}$ & $100 \%$ & Very good \\
\hline & 4. Accuracy of facts and data & $88 \%$ & Very good \\
\hline & 5. Accuracy of examples and cases & $100 \%$ & Very good \\
\hline & $\begin{array}{l}\text { 6. Accuracy of images, diagrams } \\
\text { and illustration }\end{array}$ & $100 \%$ & Very good \\
\hline & 7. Accuracy of terms & $100 \%$ & Very good \\
\hline \multirow[t]{5}{*}{$\begin{array}{l}\text { C. Proficiency of } \\
\text { Material }\end{array}$} & $\begin{array}{l}\text { 8. Compatibility of material with } \\
\text { development of science }\end{array}$ & $88 \%$ & Very good \\
\hline & $\begin{array}{l}\text { 9. Displays the topic of archipelago } \\
\text { folklore examples of children's } \\
\text { literature }\end{array}$ & $100 \%$ & Very good \\
\hline & \begin{tabular}{|l|l|} 
10.Pictures, diagrams and \\
illustrations in everyday life
\end{tabular} & $88 \%$ & Very good \\
\hline & $\begin{array}{l}\text { 11. Use examples of cases found in } \\
\text { everyday life }\end{array}$ & $100 \%$ & Very good \\
\hline & 12. Library update & $88 \%$ & Very good \\
\hline \multirow[t]{2}{*}{ D. Encourage curiosity } & 13. Encourage curiosity & $100 \%$ & Very good \\
\hline & 14. Creating the ability to ask & $100 \%$ & Very good \\
\hline \multicolumn{2}{|c|}{ Overall Average Amount } & $96.4 \%$ & Very good \\
\hline
\end{tabular}

The table above is the result of an analysis of the collected data after the validator gives an assessment of the aspect of content eligibility. Based on these results, the overall average number of aspects of the eligibility of the contents is in a very good category with a total percentage of $96.4 \%$. The acquisition scores for each content eligibility sub-component are presented in table 2 below. 
Table 2. Percentage of Assessment on Each Sub-Component of Feasibility

\begin{tabular}{|c|l|c|l|}
\hline No. & Sub Component of Assessment & Average (\%) & Criteria \\
\hline 1 & Compatibility of material with KI and KD & $100 \%$ & Very good \\
\hline 2 & Material accuracy & $97.5 \%$ & Very good \\
\hline 3 & Material update & $92.5 \%$ & Very good \\
\hline 4 & Encourage curiosity & $100 \%$ & Very good \\
\hline Rata-rata & $\mathbf{9 6 . 4 \%}$ & Very good \\
\hline
\end{tabular}

Table 3. The Assessment of Material Expert on Teaching Materials which Developed on Aspects of Presentation Feasibility

\begin{tabular}{|c|c|c|c|}
\hline Sub Component & Indicators & $\begin{array}{c}\text { Average } \\
(\%)\end{array}$ & Criteria \\
\hline \multirow[t]{2}{*}{ A. Presentation Techniques } & $\begin{array}{l}\text { 1. Systematic consistency of } \\
\text { presentation in learning } \\
\text { activities }\end{array}$ & $100 \%$ & Very good \\
\hline & 2. Grievance concept & $100 \%$ & Very good \\
\hline \multirow[t]{3}{*}{ B. Learning Presentation } & 3. Involvement of students & $75 \%$ & Good \\
\hline & 4. Student-centered & $100 \%$ & Very good \\
\hline & $\begin{array}{l}\text { 5. Stimulating students' ability } \\
\text { to solve problems through } \\
\text { illustrations }\end{array}$ & $88 \%$ & Very good \\
\hline \multirow[t]{8}{*}{ C. Presentation Completeness } & $\begin{array}{l}\text { 6. Examples of questions in } \\
\text { each activity learning }\end{array}$ & $88 \%$ & Very good \\
\hline & $\begin{array}{l}\text { 7. Practice questions at the end } \\
\text { of each learning activity }\end{array}$ & $88 \%$ & Very good \\
\hline & $\begin{array}{l}\text { 8. Key answers to practice } \\
\text { questions }\end{array}$ & $100 \%$ & Very good \\
\hline & 9. Introductin & $100 \%$ & Very good \\
\hline & 10. Table of contents & $100 \%$ & Very good \\
\hline & 11. Glossary & $88 \%$ & Very good \\
\hline & 12. References & $88 \%$ & Very good \\
\hline & 13. Summary & $88 \%$ & Very good \\
\hline \multicolumn{2}{|l|}{ Average Overall Amount } & $92.3 \%$ & Very good \\
\hline
\end{tabular}

Table 4. Percentage of Assessment in Each Sub-Component of Presentation Feasibility

\begin{tabular}{|c|l|c|l|}
\hline No & Sub Component of Assessment & $\begin{array}{c}\text { Average } \\
(\mathbf{\%})\end{array}$ & Criteria \\
\hline 1 & Presentation technique & $92.2 \%$ & Very good \\
\hline 2 & Presentation of learning & $87.5 \%$ & Very good \\
\hline 3 & Complete presentation & $92.2 \%$ & Very good \\
\hline Average & $\mathbf{9 2 . 3 \%}$ & Very good \\
\hline
\end{tabular}


Table 5. The Assessment of Material Expert on Teaching Materials which Developed on Aspects of Language Feasibility

\begin{tabular}{|c|c|c|c|}
\hline Sub Component & Indicators & Average (\%) & Criteria \\
\hline \multirow[t]{3}{*}{ A. Straightforward } & 1. Accuracy of sentence structure & $100 \%$ & Very good \\
\hline & 2. Effectiveness of sentences & $100 \%$ & Very good \\
\hline & 3. Stiffness of terms & $100 \%$ & Very good \\
\hline \multirow[t]{2}{*}{ B. Communicative } & 4. Message readability & $100 \%$ & Very good \\
\hline & 5. Accuracy of use language & $88 \%$ & Very good \\
\hline \multirow[t]{2}{*}{$\begin{array}{l}\text { C. Dialogical and } \\
\text { interactive }\end{array}$} & $\begin{array}{l}\text { 6. The ability to motivate } \\
\text { messages or information }\end{array}$ & 100 & Very good \\
\hline & $\begin{array}{l}\text { 7. The ability to encourage } \\
\text { critical thinking }\end{array}$ & $88 \%$ & Very good \\
\hline \multirow{2}{*}{$\begin{array}{l}\text { D. Conformity with the } \\
\text { level of development } \\
\text { of students }\end{array}$} & $\begin{array}{l}\text { 8. Developmental conformity } \\
\text { intellectual students }\end{array}$ & $75 \%$ & Good \\
\hline & $\begin{array}{l}\text { 9. Compliance with levels } \\
\text { emotional development of } \\
\text { students }\end{array}$ & $88 \%$ & Very good \\
\hline \multirow{2}{*}{$\begin{array}{l}\text { E. Grievance and } \\
\text { integration of the } \\
\text { mindset }\end{array}$} & $\begin{array}{c}\text { 10. Grievance and integration } \\
\text { between activities learn }\end{array}$ & $88 \%$ & Very good \\
\hline & $\begin{array}{l}\text { 11. Grievance and integration } \\
\text { between paragraph }\end{array}$ & $100 \%$ & Very good \\
\hline \multirow[t]{2}{*}{$\begin{array}{l}\text { F. Use of terms, } \\
\text { symbols and icons }\end{array}$} & $\begin{array}{l}\text { 12. Consistency in the use of } \\
\text { terms }\end{array}$ & $100 \%$ & Very good \\
\hline & $\begin{array}{l}\text { 13. consistency in the use of } \\
\text { symbols or icons }\end{array}$ & $100 \%$ & Very good \\
\hline \multicolumn{2}{|l|}{ Overall Average Amount } & $94.2 \%$ & Very good \\
\hline
\end{tabular}

Table 6. Percentage of Assessment in Each Sub Component of Language Feasibility

\begin{tabular}{|c|l|c|l|}
\hline No & Sub Component of Assessment & Average (\%) & Criteria \\
\hline 1 & Straightforward & $100 \%$ & Very good \\
\hline 2 & Communicative & $93,7 \%$ & Very good \\
\hline 3 & Dialogue and Interactive & $93.7 \%$ & Very good \\
\hline 4 & $\begin{array}{l}\text { Conformity with the level of development } \\
\text { of students }\end{array}$ & $81.3 \%$ & Very good \\
\hline 5 & Allegiance and integration of the mindset & $93,7 \%$ & Very good \\
\hline 6 & Use of terms, symbols and icons & $100 \%$ & Very good \\
\hline Average & $\mathbf{9 4 . 2 \%}$ & Very good \\
\hline
\end{tabular}


Based on the table above, it is known that the results of the percentage of the average overall rating of the language feasibility component are $94.2 \%$ with the criteria of "very good". The results of the percentage of sub-components of language feasibility assessment on $100 \%$ straightforward aspects, communicative $87.5 \%$, dialogic and interactive $93.7 \%$, suitability with the level of development of students $81.3 \%$, suitability and cohesiveness of mind flow $93.7 \%$, and the use of terms, symbols, and icons $100 \%$. Thus, it can be concluded that the teaching materials developed in the aspect of language feasibility have met the eligibility criteria of teaching materials. This can be seen from the overall number on the aspect of language feasibility, which is in the excellent category.

The aspects assessed by design experts on teaching materials developed include the size of teaching materials, cover design of teaching materials (cover), and design content of teaching materials. The assessment of the design of teaching materials developed was carried out by Dr. Daulad Saragi, M. Hum., And Dr. Mursyid, M.Pd. who are both lecturers at Medan State University. The data from the material expert validation on the aspects of content eligibility can be seen in table 7 below.

Table 7. The Assessment of Design Expert on Teaching Materials which Developed on the Aspect of graphic feasibility

\begin{tabular}{|c|c|c|c|}
\hline Component & Indicator & $\begin{array}{c}\text { Average } \\
(\%)\end{array}$ & Criteria \\
\hline \multirow[t]{2}{*}{$\begin{array}{l}\text { A. Teaching } \\
\text { Material Size }\end{array}$} & $\begin{array}{l}\text { 1. Suitability of teaching materials } \\
\text { with ISO standards (A4, A5 and } \\
\text { B5) }\end{array}$ & $100 \%$ & Very good \\
\hline & $\begin{array}{l}\text { 2. Suitability of size with the } \\
\text { material content of teaching } \\
\text { materials }\end{array}$ & $100 \%$ & Very good \\
\hline \multirow[t]{5}{*}{$\begin{array}{l}\text { B. Teaching Material } \\
\text { Design Cover }\end{array}$} & $\begin{array}{l}\text { 3. Appearance of the layout } \\
\text { elements on the front, back and } \\
\text { back covers harmoniously has a } \\
\text { rhythm and unity and is } \\
\text { consistent. }\end{array}$ & $100 \%$ & Very good \\
\hline & 4. Display a good center point. & $88 \%$ & Very good \\
\hline & $\begin{array}{l}\text { 5. The color elements of the layout } \\
\text { are harmonious and clarify the } \\
\text { function. }\end{array}$ & $100 \%$ & Very good \\
\hline & $\begin{array}{l}\text { 6. The composition and size of the } \\
\text { layout elements (title, author, } \\
\text { illustration, logo, etc.) are } \\
\text { proportional, balanced, and in } \\
\text { line with the content layout } \\
\text { (according to the pattern). }\end{array}$ & $100 \%$ & good \\
\hline & $\begin{array}{l}\text { 7. The font size of the teaching } \\
\text { material title is more dominant } \\
\text { and proportional than the size of } \\
\text { the teaching material, the name } \\
\text { of the author. }\end{array}$ & $100 \%$ & Very good \\
\hline
\end{tabular}




\begin{tabular}{|c|c|c|c|}
\hline & $\begin{array}{l}\text { 8. The color of the title of the } \\
\text { teaching material contrasts with } \\
\text { the background color. }\end{array}$ & $75 \%$ & Very good \\
\hline & $\begin{array}{l}\text { 9. Don't use too many font } \\
\text { combinations. }\end{array}$ & $88 \%$ & Very good \\
\hline & $\begin{array}{l}\text { 10. Describe the content / teaching } \\
\text { material and reveal the } \\
\text { character of the object. }\end{array}$ & $88 \%$ & good \\
\hline & $\begin{array}{l}\text { 11. Shape, color, size, proportion } \\
\text { of objects according to reality. }\end{array}$ & $100 \%$ & Very good \\
\hline C. Design of teaching & Suitability of media / illustrations $w$ & h stories & \\
\hline material contents & $\begin{array}{l}\text { 12. Placement of comics according } \\
\text { to the contents of the story }\end{array}$ & $100 \%$ & Very good \\
\hline & 13. Comics direct the storyline & $100 \%$ & Very good \\
\hline & $\begin{array}{l}\text { 14. Comics express the character } \\
\text { of an object }\end{array}$ & $100 \%$ & Very good \\
\hline & Layout Consistency & & \\
\hline & $\begin{array}{l}\text { 15. Element placement of } \\
\text { consistent layout is based on } \\
\text { pattern }\end{array}$ & $75 \%$ & Very good \\
\hline & $\begin{array}{l}\text { 16. Separation between paragraphs } \\
\text { is clear }\end{array}$ & $88 \%$ & Very good \\
\hline & Harmonious Layout Element & & \\
\hline & $\begin{array}{l}\text { 17. Printing area and proportional } \\
\text { margin }\end{array}$ & $100 \%$ & Very good \\
\hline & $\begin{array}{l}\text { 18. The two-page margin is side } \\
\text { by side proportional }\end{array}$ & $100 \%$ & good \\
\hline & $\begin{array}{l}\text { 19. Spaces between text and } \\
\text { illustrations are appropriate }\end{array}$ & $75 \%$ & good \\
\hline & Complete Layout Element & & \\
\hline & $\begin{array}{l}\text { 20. Placement of learning activity } \\
\text { titles, subtitles of learning } \\
\text { activities, and exact page / } \\
\text { folio numbers } \\
\end{array}$ & $100 \%$ & Very good \\
\hline & $\begin{array}{l}\text { 21. Illustration placement and } \\
\text { caption right }\end{array}$ & $88 \%$ & Very good \\
\hline & Page Speeding Layout & & \\
\hline & $\begin{array}{l}\text { 22. Placement of decoration / } \\
\text { illustration as background } \\
\text { does not interfere with } \\
\text { title, text, page numbers. }\end{array}$ & $100 \%$ & Very good \\
\hline & $\begin{array}{l}\text { 23. Position placement, subtitles, } \\
\text { illustrations, and image } \\
\text { captions do not depend on } \\
\text { understanding. } \\
\end{array}$ & $100 \%$ & Very good \\
\hline
\end{tabular}




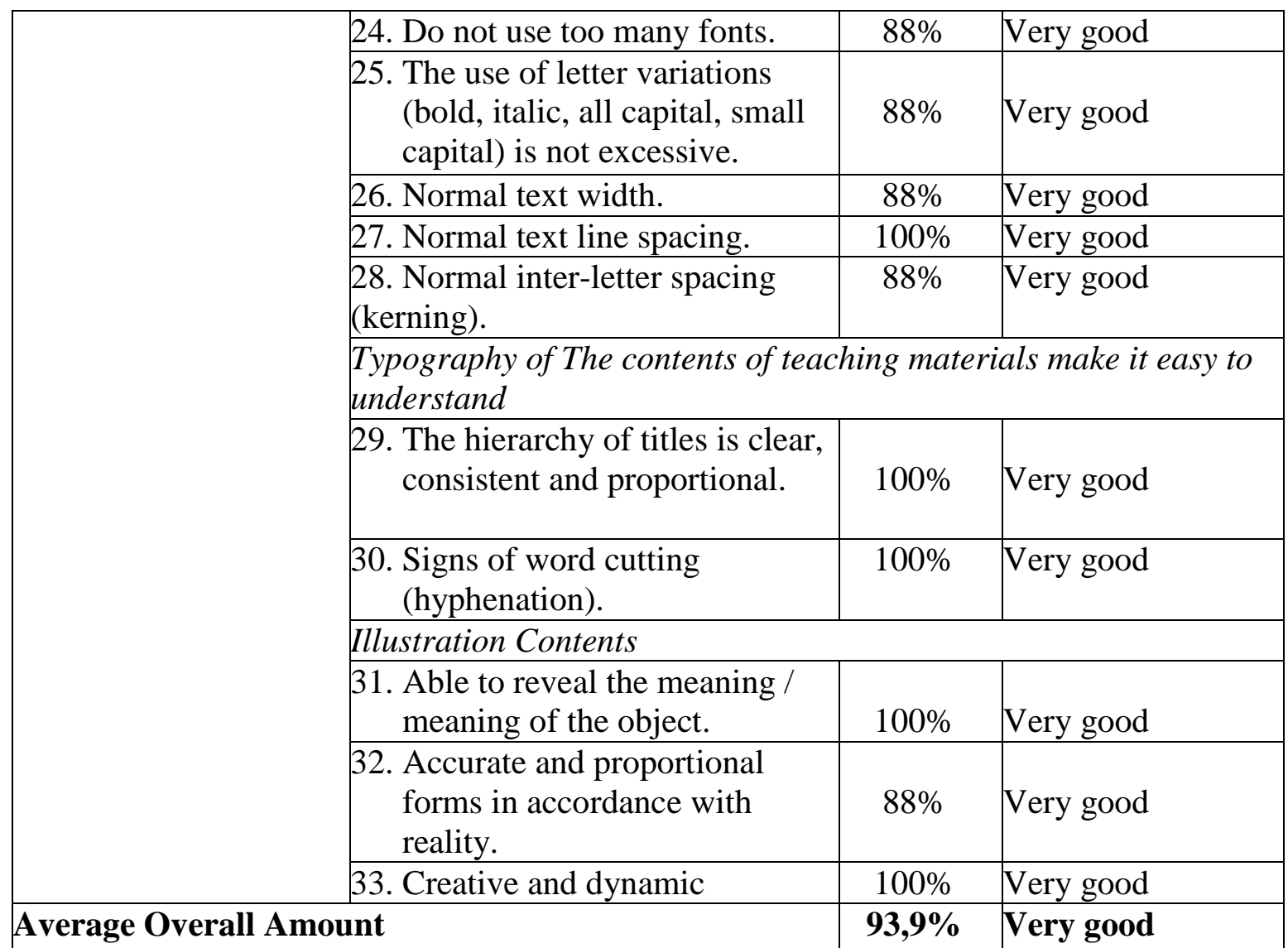

Table 8. Percentage of Assessment in Each Sub-Component of Graphic Feasibility

\begin{tabular}{|c|l|c|l|}
\hline No. & Sub Component of Assessment & Average (\%) & Criteria \\
\hline 1 & Size of teaching materials & $100 \%$ & Very good \\
\hline 2 & Design of teaching material cover & $93.1 \%$ & Very good \\
\hline 3 & $\begin{array}{l}\text { Design of the contents of teaching } \\
\text { materials }\end{array}$ & $93.7 \%$ & Very good \\
\hline Average & $\mathbf{9 3 . 9 \%}$ & Very good \\
\hline
\end{tabular}

\subsection{Results of Assessment of Indonesian Teachers on Developed Learning Materials}

The assessment of teaching materials which developed is of course also inseparable from observations from the relevant subject matter teachers to improve the quality or quality of the teaching materials developed. The assessment of the teaching materials developed was conducted by Ratna Sari Lubis, S.Pd. and Rodiah S.Pd. that are teachers who are directly related to the field of learning in SD Negeri 067091 Medan Kota District. The data on the results of responses or teacher responses to teaching materials developed in module form are presented in the following table 9 . 
Table 9. Teacher Response Data on Developed Learning Materials

\begin{tabular}{|c|c|c|c|}
\hline No. & Indicators & $\begin{array}{l}\text { Average } \\
\text { Score }(\%)\end{array}$ & Criteria \\
\hline 1 & $\begin{array}{l}\text { Module appearance with literary material } \\
\text { Text-based archipelago children as a } \\
\text { whole are interesting }\end{array}$ & $100 \%$ & Very good \\
\hline 2 & $\begin{array}{l}\text { The language used in the literature module } \\
\text { Text-based archipelago children are easy } \\
\text { to understand }\end{array}$ & $100 \%$ & Very good \\
\hline 3 & $\begin{array}{l}\text { Presentation of children's literature in modules is } \\
\text { arranged systematically }\end{array}$ & $100 \%$ & Very good \\
\hline 4 & $\begin{array}{l}\text { Children's literature material in the module is in } \\
\text { accordance with the learning objectives }\end{array}$ & $100 \%$ & Very good \\
\hline 5 & The use of color images in the module is clear & $88 \%$ & Very good \\
\hline 6 & $\begin{array}{l}\text { Stimulating learning activities } \\
\text { critical thinking skills }\end{array}$ & $88 \%$ & Very good \\
\hline 7 & $\begin{array}{l}\text { Type of activity in the children's literature module } \\
\text { varies }\end{array}$ & $100 \%$ & Very good \\
\hline 8 & $\begin{array}{l}\text { The latest information in the module is in } \\
\text { accordance with the development of science and } \\
\text { technology }\end{array}$ & $100 \%$ & Very good \\
\hline 9 & $\begin{array}{l}\text { Use of symbols in accordance with the rules } \\
\text { which exists }\end{array}$ & $100 \%$ & Very good \\
\hline 10 & $\begin{array}{l}\text { The module helps students understand the } \\
\text { archipelago-based children's literature learning } \\
\text { material } \\
\text { text }\end{array}$ & $100 \%$ & Very good \\
\hline 11 & $\begin{array}{l}\text { This text-based archipelago children's literature } \\
\text { module is different from the usual teaching material }\end{array}$ & $100 \%$ & Very good \\
\hline 12 & $\begin{array}{l}\text { This children's literature module can be studied } \\
\text { independently by students }\end{array}$ & $100 \%$ & Very good \\
\hline 13 & $\begin{array}{l}\text { The children's literature module trains students to } \\
\text { enrich knowledge }\end{array}$ & $88 \%$ & Very good \\
\hline 14 & $\begin{array}{l}\text { The children's literature module makes it easier for } \\
\text { teachers to evaluate students }\end{array}$ & $88 \%$ & Very good \\
\hline 15 & $\begin{array}{l}\text { Modules make it easy for students to express their } \\
\text { opinions in oral or written form }\end{array}$ & $100 \%$ & Very good \\
\hline \multicolumn{2}{|r|}{\begin{tabular}{|l|l} 
Total average score & \\
\end{tabular}} & $96.7 \%$ & Very good \\
\hline
\end{tabular}

The results of the teacher's response to the teaching materials developed in the table above obtained a total percentage of the overall average of $96.7 \%$ with the criteria of "very good". Thus it can be concluded that the quality or quality of the teaching material developed has met the criteria for developing appropriate teaching materials so that it has great potential to be applied in the teaching and learning process in the classroom. 


\subsection{Product Revisions}

Product revisions are carried out in stages after the preparation of teaching materials is said to be completed. The first stage begins with validating the product to a team of experts who are in accordance with their respective fields, namely to the material and design experts. After the product validation stage is complete, it is followed by asking the teacher or student response or response to the instructional material developed. To see the results and effectiveness of the products being developed, it is necessary to do a thorough trial of the subject, namely by testing a small group up to a limited group trial. For more details, the following are the stages of product revision being developed.

\section{First revision}

The researcher conducted a revision of teaching materials developed based on suggestions or improvements proposed by material experts and design. In other words, faceto-face meetings are only conducted twice, namely the first meeting of the material and design expert team provides suggestions as well as evaluating the instructional materials developed. As for the second meeting, the expert team is only limited to conducting a substantial examination of the improvements that have been made by the researcher to the instructional materials developed and providing final scores. The suggestions from the whole team of experts, both verbally and in writing are summarized in general as follows.

a. To be more communicative in improving the use of words or terms.

b. Presentation of material in teaching materials is deepened so that students' understanding is more accurate.

c. The source or reference referred to in the teaching material must be clear.

d. Re-examine examples and concepts in presenting information or knowledge to make it easier for students to understand.

e. Paper size in the preparation of teaching materials adjusted based on predetermined size.

f. The cover, name of the author, page, and presentation of images in the teaching materials need to be revised again.

g. Must be consistent with the choice of letters so that they can be read clearly.

h. Learning activities in the module must be in accordance with the concept map that has been designed.

The validation stage is carried out 2 times. In the first face-to-face meeting, material and design experts gave their criticism of the teaching materials being developed. After suggestions for improvement have been collected through material and design experts, researchers then make improvements in accordance with the directions of the expert team. The next meeting was held. For this second meeting, the validators only gave a final assessment while looking at the improvements made by the researchers. As for the overall results given by the expert team on the aspect of content eligibility were declared "very good" with a total percentage of 96, $4 \%$, the feasibility of presentation was stated to be "very good" with a total percentage of $92.3 \%$, language eligibility was "very good" with a total percentage of $94,2 \%$, and the feasibility of graphics is declared "very good" with a total percentage of $93.9 \%$. 


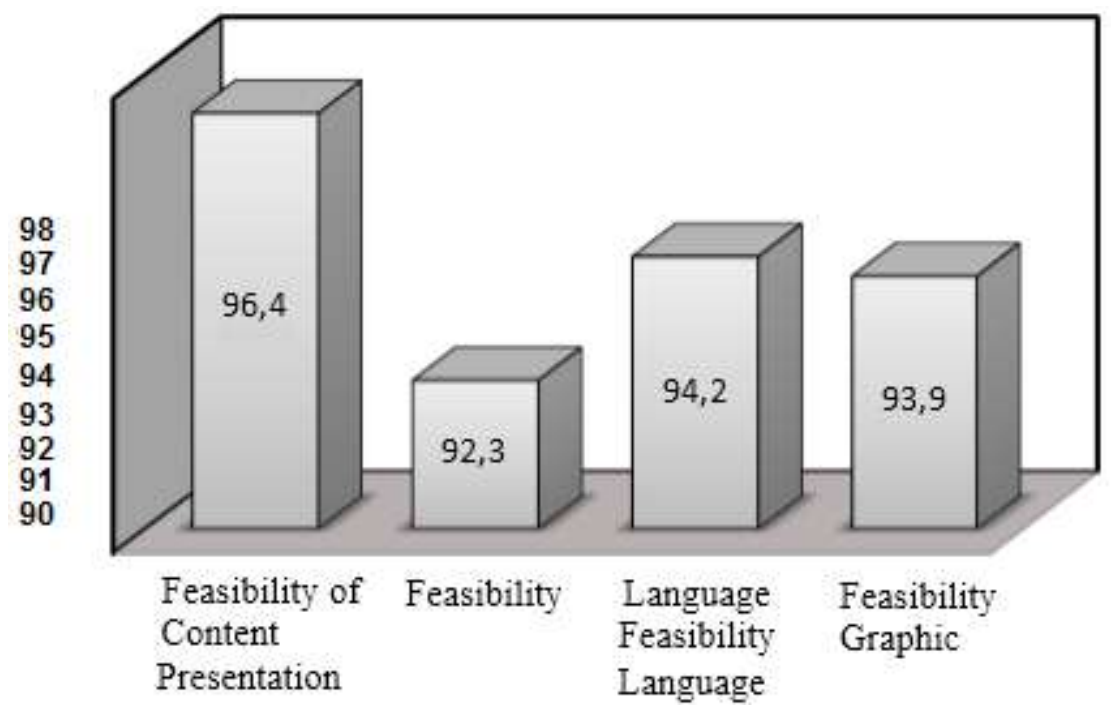

Figure 1. The Assessment of Material and Design Expert Team Results on Developed Learning Material

Based on the graph shown in Figure 4.2 above, it can be concluded that the teaching material developed has been worthy of being tested based on the final score given by the two expert teams, both the material expert team and the teaching material design. The feasibility can be seen from the results of data analysis from the two experts which shows that the developed teaching materials are worthy of being tested at the next stage.

\section{Second Revision}

The next trial was carried out by involving 2 Indonesian language teachers in SD 067091, Medan Kota District. The involvement of these two teachers aims to get responses or responses to teaching materials developed. In addition, these two teachers can also give their assessment or suggestions through questionnaires given to teaching materials to suit the subject's meticulous objectives in the field. From the questionnaire given to the two teachers, suggestions were obtained in the form of insufficient substantial improvements to the material and design of the teaching materials developed. Improvements in teaching teaching materials are limited to letters, spelling, punctuation, and less communicative sentences. The ineffectiveness of the sentence also became part of the spotlight of these two teachers. After repairs to some suggestions from the two teachers, they immediately gave a final response or assessment of the instructional materials developed. The instructional materials developed obtained an assessment with a total percentage of $96.7 \%$ with the criteria of "very good" so that the teaching materials were worthy of being used as a source of information or knowledge in the teaching and learning process.

\section{Third Revision}

The revision stages in the process of developing teaching materials require not a little time. In addition to asking for responses or responses from experts and teachers, we must also ask for responses or responses from the test subjects, namely students in accordance with the flow of research and development. Trials given to students go through the process of individual trials, small group trials, and limited group trials. The purpose of this trial is to see all kinds of symptoms that can hinder the provision of information to conscientious subjects in the learning process in accordance with the content of the questionnaire distributed. 


\subsection{Discussion of Research Results}

The purpose of research and development of teaching materials for class V students of SD Negeri 067091 Medan Kota District was carried out to produce products in the form of literary teaching materials with integrated material from many children's literature in the archipelago. This research and development is not only limited to producing products, but also provides comparisons to researchers and related parties after testing the effectiveness of the product so that it can be used by students and teachers during the teaching and learning process. Thus, the process of research and development of teaching materials is a complicated activity to produce a quality product that overrides the author's assumptions.

The process of research and development of teaching materials must go through various stages, including (1) Conducting preliminary studies by means of observation and literature. Observations are made to provide initial information to researchers about the problems faced by students in learning. After observations are carried out, it is necessary to do a study or literature review to gather as much information as possible about the problems found during the observation activities in the field. From the results of observations and reinforced by preliminary studies found by researchers, it can be given a temporary conclusion that students need teaching materials. (2) Designing products to produce initial products for teaching materials. This activity is carried out by referring to the preliminary study and mapping the Competency Standards and Basic Competencies that will serve as the basis for product development. (3) Develop teaching materials. Developing teaching materials has begun at the preparation stage of teaching materials, for example introductory words, KI and KD which are the focus of student learning, learning activities, and bibliography. (4) Designing learning activities includes learning material, summaries, tests, and answer keys. (5) Perform validation and revision. This activity includes product assessment by material experts and learning design to find out the strengths and weaknesses of teaching materials designed by researchers. After the assessment was given by the expert team, the results were made as material for revision by the researcher. (6) Evaluating the results of responses or responses given by teachers to teaching materials developed through questionnaires that were previously distributed. These results are used as assessment material before being tested on students. (7) Conduct individual trials, small group trials, and limited field trials. This activity was also carried out so that the products produced in the form of text-based teaching materials for children of the archipelago literature became more quality because they had involved students as the subject of this research. Furthermore, to test the effectiveness of the use of the products developed, students are given a final test to measure students' understanding of the material presented in the textbased archipelago children's literature teaching material. The effectiveness of this product will be seen from the comparison of student learning outcomes before and after using instructional materials developed.

The flow of research and development of teaching materials has been described clearly in the previous section. Before it was known that the effectiveness of the product being developed was disclosed, sometimes the results of validation by material and design experts were described first. The results of the validation provided by the material experts on the teaching materials developed obtained content eligibility of $96.4 \%$ with very good criteria, the feasibility of presentation was $92.3 \% \%$ with very good criteria, and language feasibility of $94.2 \%$ with very criteria well. The results of the average percentage of the overall subcomponent of the material expert assessment amounted to $93.3 \%$ with very good criteria. Furthermore, the results of validation by design experts on teaching materials developed in sub-components of material size were $100 \%$ with very good criteria, the cover design of 
teaching materials was $93.1 \%$ with very good criteria, and the design content of teaching materials was $93.7 \%$ with very good criteria. The results of the average percentage of the overall sub-component assessment of design experts or learning media is $93.9 \%$ with the criteria of "very good".

The description of the results of the material feasibility and design of the teaching materials developed was concluded that the text-based children's literature teaching material had met the eligibility criteria based on the results of the analysis of the results of feasibility provided by the expert team. Thus, the text-based children's literature teaching materials have fulfilled the provisions by applying the standards for the assessment of teaching materials and are feasible to be tested in the field to the research subjects.

After the results of the performance of teaching materials are presented from material experts and the design is said to be feasible, the results of the teacher's response or response are also the same, namely getting a fairly high response. This was revealed from the results of the analysis carried out by the researcher on the questionnaire that had been previously shared with the two teachers at the SD Negeri 067091 school in Medan Kota Subdistrict with a response rate of $96.7 \%$ or in very good criteria. The result of the response or response is a positive response to the teaching material developed by the researcher because it is one of the keys to enter in conducting further research based on the flow and development of teaching materials so that the material developed is guaranteed quality at the implementation stage.

The process of research and development of teaching materials is not enough to arrive at the stage of data collection in the form of teacher responses and responses, but more deeply on the subject that was actually used as the subject of research, namely class V 067091 Elementary School District Medan Kota District. The students need to be asked for their responses and responses to the teaching materials developed in order to maintain and guarantee the quality of the teaching materials later. As for the data in the form of responses and responses of students after the data analysis was conducted it was found that (1) the average percentage of individual trials was in good criteria with a total percentage of $79.2 \%$, (2) small group trials were in very good criteria with a total percentage of $82.4 \%$, and (3) limited field trials are in very good criteria with a total percentage of $98.03 \%$. Thus, the overall data analysis shows that the teaching material developed has been feasible in the trial phase on the subject that is the focus of the research.

\section{Conclusion}

Text-based archipelago children's literature teaching products which is developed to support elementary school literary learning meet the requirements and are feasible to use based on material and design expert validation. Material validation includes the feasibility of filling the average score of $96.4 \%$ with very good criteria, the feasibility of presentation the average score of $92.3 \%$ with very good criteria, and the feasibility of language the average score of $94.2 \%$. Then, the validation of expert design the average score of $93.9 \%$ with very good criteria.

The response to archipelago children literature teaching materials on text-based in literary material is very good and in accordance with the needs of students, that is the average score of $96.7 \%$ for the results of data analysis for 2 teachers and $98.03 \%$ for the analysis of data from 18 students overall. The use of archipelago children literature teaching materials on text-based is more effective in improving student learning outcomes. This was revealed from the student learning outcomes after being taught with developed teaching materials, namely an 
increase in learning outcomes from the average 78.98 with a good category to 86.11 with a very good category.

\section{References}

Depdiknas. 2004. Kurikulum 2004: Standar Kompetensi Pendidikan Usia Dini (Taman KanakKanak dan Raudhotul Athfal.Jakarta: Pusat Kurikulum, Balitbang Diknas..

Djajanegara, Soenarjati. 2000. Kritik Sastra Feminism Sebuah Pengantar. Jakarta: Gramedia.

Huck, Charlotte S, Susasn Hepler, and Janes Hickman. 1987. Children's Literature in The Elementary School. New York: Holt, Rinehart and Winston.

Hunt, Peter. 1995. Criticism, Theory, and Children's Literature. Cambridge, Massacusetts: Blackwell.

Jamaris, Martini. 2006. Perkembangan dan Pengembangan Anak Usia TamanKanak-Kanak. Jakarta: Grassindo..

Marwati Djoened \& Nugroho Notosusanto, 1993. Sejarah nasional Indonesia II. Jakarta: Balai Pustaka

McCloud, Scoot. 2002. Understanding Comic, Memahami KomikJakarta:KPG (Kepustakaan Populer Gramedia) (translated S Kinanti ).

Puryanto, Edi. 2008. Konsumsi Anak dalam Teks Sastra di Sekolah.-dalam Konferensi Internasional Kesusastraan XIX HISKI. ).

Riffaterre, Michael. 1978. Semiotics of Poetry. Bloomington \& London: Indoana University Press.

Santoso, Soegeng. 2006. Dasar-Dasar Pendidikan TK. Jakarta: Universitas Terbuka.

Saxby, Maurice and Gordon Winch. 1991. Give Them Wings, The Experiences of Children's Literature. Melbourne: The Macmillan Company.

Sihotang, Candra. 2015. Tesis. Pengembangan Buku Ajar Berbasis Kontekstual dengan Tema "Sehat itu Penting" Siswa Kelas V Madrasah Ibtidaiyah Negeri Sibulussalam. Medan: Unversitas Negeri Medan.

Stewig, John Warren. 1980. Children and Literature. Chicago: Rand McNally College Publishing Company.

Sugiyono. 2015. Metode Penelitian Kuantitatif, Kualitatif dan $R \&$ D. Bandung: Alfabeta.

Suyanto, Slamet. 2005. Dasar-Dasar Pendidikan Anak Usia Dini. Yogyakarta: Hikayat Publishing.

Trimansyah, Bambang. 1999. Fenomena Intrinsik Cerita Anak Indonesia Kontemporer: Dunia Sastra yang Terpinggirkan. Bandung: Nuansa.

Triwikromo, Triyanto. 2004. "Kekerasan pada Perempuan dalam Cerita Anak" dalam Kedaulatan Rakyat. Yogyakarta: KR.

Wellek, Rene. 1990. Teori Kesusastraan (Terjemahan). Jakarta: Gramedia.

Widyariani, dkk. 2016. Pengembangan Bahan Ajar Berbasis Konteks dan Kreativitas untuk Melatihkan Literasi Sains Siswa Sekolah Dasar. Universitas Muhammadiyah Sukabumi. Journal of Bioedukatika. Volume 4 No. 2.

Witakania. 2008. Aspek Psikopedagogik dalam Sastra Anak

Yuwono, K.S. 2007.Pengantar Sejarah Sastra. Jakarta: PT. Grasindo 